\title{
New free-living nematode species and records (Chromadorea: Plectida and Desmodorida) from the edge and axis of Kermadec Trench, Southwest Pacific Ocean
}

\author{
Daniel Leduc ${ }^{\text {Corresp. } 1}$ \\ ${ }^{1}$ National Institute of Water and Atmospheric Research, Wellington, New Zealand \\ Corresponding Author: Daniel Leduc \\ Email address: daniel.leduc@gmail.com
}

One new nematode species is described and two new species records are provided from the edge (6080 m depth) and axis (7132 m) of Kermadec Trench, Southwest Pacific. Leptolaimus hadalis sp. nov. is characterised by medium body 587-741 $\mu \mathrm{m}$ long, labial region not offset from body contour, inconspicuous labial sensilla, amphid located 12-19 $\mu \mathrm{m}$ from anterior end, female without supplements, male with four tubular precloacal supplements (alveolar supplements absent), tubular supplements almost straight with dentate tip, arcuate spicules and weakly cuticularized dorsal gubernacular apophyses strongly bent distally. In a previously published ecological survey of Kermadec Trench, $L$. hadalis sp. nov. was the most abundant species in a core obtained at $8079 \mathrm{~m}$ water depth and third most abundant species in a core obtained at $7132 \mathrm{~m}$, while only one individual was found at $6096 \mathrm{~m}$ depth, and none at $9175 \mathrm{~m}$ depth (Leduc \& Rowden 2018). Alaimella aff. cincta and Desmodora aff. pilosa are recorded for the first time from the Southwest Pacific region. Prior to the present study, Alaimella had only been recorded from coastal locations and from the Weddell sea to a depth of $2000 \mathrm{~m}$. The record of Desmodora aff. pilosa at $6080 \mathrm{~m}$ depth is the deepest record of a Desmodora species to date, although unidentified Desmodora specimens have been found as deep as $6300 \mathrm{~m}$ in the South Sandwich Trench. The morphology of the Kermadec Trench Alaimella aff. cincta and Desmodora aff. pilosa specimens bear a strong resemblance to their respective type populations from the Northern Hemisphere, but further morphological and molecular data are required to ascertain whether they in fact represent distinct species. 
1 New free-living nematode species and records

2 (Chromadorea: Plectida and Desmodorida) from the edge

3 and axis of Kermadec Trench, Southwest Pacific Ocean 4 5

6 Daniel Leduc

7

8 National Institute of Water and Atmospheric Research, Wellington, New Zealand 9

10 Corresponding Author:

11 Daniel Leduc

12301 Evans Bay Parade, Wellington, 6021, New Zealand

13 Email address: Daniel.Leduc@niwa.co.nz

14 
15

16

17

18

19

20

\section{Abstract}

One new nematode species is described and two new species records are provided from the edge (6080 m depth) and axis (7132 m) of Kermadec Trench, Southwest Pacific. Leptolaimus hadalis sp. nov. is characterised by medium body 587-741 $\mu \mathrm{m}$ long, labial region not offset from body contour, inconspicuous labial sensilla, amphid located 12-19 $\mu \mathrm{m}$ from anterior end, female without supplements, male with four tubular precloacal supplements (alveolar supplements absent), tubular supplements almost straight with dentate tip, arcuate spicules and weakly cuticularized dorsal gubernacular apophyses strongly bent distally. In a previously published ecological survey of Kermadec Trench, L. hadalis sp. nov. was the most abundant species in a core obtained at $8079 \mathrm{~m}$ water depth and third most abundant species in a core obtained at 7132 $\mathrm{m}$, while only one individual was found at $6096 \mathrm{~m}$ depth, and none at $9175 \mathrm{~m}$ depth (Leduc \& Rowden 2018). Alaimella aff. cincta and Desmodora aff. pilosa are recorded for the first time from the Southwest Pacific region. Prior to the present study, Alaimella had only been recorded from coastal locations and from the Weddell sea to a depth of $2000 \mathrm{~m}$. The record of Desmodora aff. pilosa at $6080 \mathrm{~m}$ depth is the deepest record of a Desmodora species to date, although unidentified Desmodora specimens have been found as deep as $6300 \mathrm{~m}$ in the South Sandwich Trench. The morphology of the Kermadec Trench Alaimella aff. cincta and Desmodora aff. pilosa specimens bear a strong resemblance to their respective type populations from the Northern Hemisphere, but further morphological and molecular data are required to ascertain whether they in fact represent distinct species.

\section{Introduction}

Unlike most other metazoans, nematodes communities in hadal trenches (> $6000 \mathrm{~m}$ depth) are characterized by relatively high abundances and species richness despite extreme conditions (Zeppilli et al. 2018). A study of three hadal sites in Puerto Rico Trench (Northeast Atlantic) revealed the presence of almost 150 morphospecies (Tietjen 1989), whilst 109 morphospecies were identified from four sites in Kermadec Trench in the Southwest Pacific (Leduc \& Rowden 2018), and 36 morphospecies were identified in cores from Tonga Trench's deepest point (Southwest Pacific; Leduc et al. 2016). 
In order to understand patterns and drivers of benthic diversity within and across trench habitats, it is necessary to better describe the hadal nematode fauna. However, most of these hadal species are yet to be described and named. In their review of deep-sea nematode taxonomy, Miljutin et al. (2010) showed that only 10 named species had so far been recorded from $>6000 \mathrm{~m}$ depth, compared to 210 named species from abyssal plains (4000-6000 m depth). The same authors listed 46 bathyal and/or abyssal nematode species which are found in more than one ocean, suggesting a cosmopolitan distribution. Leduc \& Rowden (2018) have shown that the adjacent Kermadec and Tonga trenches share 33 morphospecies, however no other studies have yet compared the nematode species composition between trenches, and it is not clear whether any hadal nematode species has a wide geographical distribution within or across ocean basins. In order to facilitate comparison of hadal nematode fauna across trenches, detailed morphological descriptions of one new species and two new species records are provided from the edge and axis of Kermadec Trench.

\section{Materials \& Methods}

The Kermadec Trench extends from approximately from 26 to $36^{\circ} \mathrm{S}$ near the northeastern tip of New Zealand, Southwest Pacific. Sediment samples were obtained from the edge of Kermadec Trench at $6080 \mathrm{~m}$ depth during $R V$ Tangaroa cruise TAN1711 in December 2017 using a USNEL-type box corer (dimensions: $0.5 \times 0.5 \times 0.5 \mathrm{~m}, 0.125 \mathrm{~m}^{3}$ capacity). Subsamples were obtained using a cut-off syringe with $29 \mathrm{~mm}$ internal diameter to a depth of $10 \mathrm{~cm}$, sliced into 1 $\mathrm{cm}$ layers and fixed in 10\% buffered formalin. Additional samples were collected from the axis of Kermadec Trench at 7132 and 8079 m depth during Woods Hole Oceanographic Institute (WHOI) cruise TN309 ( $R V$ Thomas G Thompson) in May 2014 (Leduc \& Rowden 2018). The sediment cores were obtained using the submersible Nereus (core internal diameter $=6.35 \mathrm{~cm}$ ). The cores were sliced into $0-1,1-2,2-3,3-4,4-5$ and 5-10 cm layers and fixed in 10\% buffered formalin. Samples were rinsed on a $20 \mu \mathrm{m}$ sieve using freshwater, nematodes extracted from the remaining sediments by Ludox flotation, stained with Rose Bengal, and transferred to pure glycerol (Somerfield \& Warwick 1996).

Species descriptions were made from glycerol mounts using differential interference contrast microscopy and drawings were made with the aid of a camera lucida. Measurements 
74 were obtained using an Olympus BX53 compound microscope with cellSens Standard software.

75 All measurements are in $\mu \mathrm{m}$, and all curved structures are measured along the arc. The terminology used for describing the arrangement of morphological features such as setae follows Coomans (1979). Type specimens are held in the NIWA Invertebrate Collection (Wellington). The collection of sediment samples was conducted under Special permit 666 to NIWA granted by New Zealand's Ministry for Primary Industries.

\section{Abbreviations:}

a: body length/maximum body diameter

b: body length/pharynx length

c: body length/tail length

$c^{\prime}$ : tail length/anal or cloacal body diameter

cbd: corresponding body diameter

L: total body length; $n$, number of specimens

$\mathrm{V}$ : vulva distance from anterior end of body

$\% \mathrm{~V}: \mathrm{V} /$ total body length $\times 100$

The electronic version of this article in Portable Document Format (PDF) will represent a published work according to the International Commission on Zoological Nomenclature (ICZN), and hence the new names contained in the electronic version are effectively published under that Code from the electronic edition alone. This published work and the nomenclatural acts it contains have been registered in ZooBank, the online registration system for the ICZN. The ZooBank LSIDs (Life Science Identifiers) can be resolved and the associated information viewed through any standard web browser by appending the LSID to the prefix http://zoobank.org/. The LSID for this publication is: urn:Isid:zoobank.org:pub:47EF84F2-7B80-460E-BAF0747FA9DDD447. The online version of this work is archived and available from the following digital repositories: PeerJ, PubMed Central and CLOCKSS.

\section{Systematics}


101

102

103

104

105

106

107

108

109

110

111

112

113

114

115

116

117

118

119

120

121

122

123

124

125

Order Plectida Gadea, 1973

Family Leptolaimidae Örley, 1880

Genus Leptolaimus de Man, 1876

Generic diagnosis: (from Holovachov (2014)) Lateral alae present. First annule anterior to cephalic setae bases and amphids, cephalic capsule absent. Cephalic sensilla papilliform or setiform. Amphideal aperture ventrally unispiral, without central elevation. Secretory-excretory system present; excretory canal short, excretory ampulla present. Ovary branches reflexed antidromously. Alveolar or tubular supplements present in females of some species, either in pharyngeal or pre-anal regions, or in both positions. Male reproductive system diorchic. Number of supplements varies from zero to 40 for alveolar and zero to 11 for tubular; males may have both types of supplements, one or no supplements at all. Caudal glands and spinneret present or absent.

Type species: L. papilliger de Man, 1876

Remarks. The genus was revised by Holovachov and Boström (2013) who provided a key to the identification of all 58 valid species based on features of both males and females. Three species were subsequently described by Tchesunov (2015), Qiao et al. (2020) and Leduc (2020).

\section{Leptolaimus hadalis sp. nov.}

Figs. 1-3, Table 1

urn:1sid:zoobank.org:act:892D1646-DD68-4601-A12C-BA26A88E1B1A

Type locality: Kermadec Trench, $7132 \mathrm{~m}$ water depth, sediment depth 0-2 cm, $R V$ Thompson voyage $\mathrm{TN} 309$, stations $\mathrm{N} 073,35.8396^{\circ} \mathrm{S}, 178.879^{\circ} \mathrm{W}$.

Type material: Holotype male (NIWA 154899), and three paratype males and three paratype females (NIWA 154900), collected in May 2014.

Measurements: See Table 1 for detailed measurements. 
Description: Male. Body colourless, tapering slightly towards both extremities, with tail

127

128

129

130

131

132

133

134

135

136

137

138

139

or posterior body region curved ventrally (maybe as a result of formalin fixation). Cuticle annulated, annules ca. $1.2 \mu \mathrm{m}$ apart; lateral alae present consisting of raised, non-annulated cuticle ca. 2-3 $\mu \mathrm{m}$ wide extending from posterior to first (anterior-most) body pore to anterior portion of tail. Four longitudinal rows of sublateral body pores, extending from near level of nerve ring to two thirds of tail length; anterior-most pore without seta, all other pores each with seta, 2-4 $\mu \mathrm{m}$ long; epidermal glands not observed. Sparse subventral and subdorsal somatic setae present on tail, 2-3 $\mu \mathrm{m}$ long. Labial region truncate to slightly rounded, not offset from body contour, lips fused. Inner and outer labial sensilla indistinct; cephalic sensilla setiform, 0.40-0.50 cbd long. Ocelli absent. Amphideal fovea round or slightly oval, located near middle or slighty posterior to middle of buccal cavity. Buccal cavity uniformly tubular: cheilostom and gymnostom short, undifferentiated; stegostom tubular, with uniformly thickened lumen. Pharynx muscular, cylindrical anteriorly, with distinct oval basal bulb, slightly cuticularized lumen from posterior to buccal cavity to near posterior end of pharynx; valvular apparatus absent. Pharyngeal glands and their orifices indistinct. Nerve ring surrounding pharynx slightly posterior to middle of pharynx length. Secretory-excretory system not observed. Cardia cylindrical, 7-11 $\mu \mathrm{m}$ long, not embedded in intestine

Reproductive system diorchic with opposed and outstretched testes; anterior testis located to the right of intestine with large, almost square sperm cells, $11 \times 11 \mu \mathrm{m}$, posterior testis located to the right of intestine or ventrally, with small globular sperm cells, ca. $1.5 \times 1.5 \mu \mathrm{m}$. Spicules paired, symmetrical, arcuate, 1.1-1.4 cloacal body diameter long, cuticularised; capitulum slightly rounded, shaft and blade gradually tapering distally. Gubernaculum with weakly cuticularized, dorsal apophysis with strongly curved distal portion; curved portion not always discernible. Ventral precloacal seta not observed. Accessory apparatus composed of four, midventral tubular supplements ca. 19-38 $\mu \mathrm{m}$ apart, the two anterior-most supplements slightly further apart than the other supplements; tubular supplements14 $\mu \mathrm{m}$ long, almost straight, slightly swollen proximally and with dentate tips, opening into shallow, cup-shaped, cuticularized depression in cuticle. Tail conico-cylindrical; three caudal glands and spinneret present. 
Females. Similar to males, but with lower values of 'a', smaller amphids and longer tail.

156 Reproductive system with two opposed reflexed ovaries; anterior ovary to the right of intestine

157

158

159

160

161

162

163

164

165

166

167

168

169

170

171

172

173

174

175

176

177

178

179

180

181

182

183

184

and posterior ovary to the left of intestine. Spermatheca present in each genital branch. Vulva situated near mid-body. Vagina perpendicular, short, proximal portion encircled by single sphincter muscle and with slight cuticularisation distally. Vaginal glands not observed. Supplements absent.

Diagnosis: Leptolaimus hadalis sp. nov. is characterised by medium body $587-741 \mu \mathrm{m}$ long, labial region not offset from body contour, inconspicuous labial sensilla, cephalic setae 0.4$0.5 \mu \mathrm{m}$ long, buccal cavity 20-29 $\mu \mathrm{m}$ long, amphid located 12-19 $\mu \mathrm{m}$ from anterior end, female without supplements, male with four tubular precloacal supplements (alveolar supplements absent), tubular supplements almost straight with dentate tip, spicules arcuate, 22-24 $\mu \mathrm{m}$ or 1.11.4 cloacal body diameters long, and weakly cuticularized dorsal gubernacular apophyses strongly bent distally.

Differential diagnosis: The new species is most similar to L. gerlachi Murphy, 1966, L. praeclarus Timm, 1961, L. nonus Holovachov \& Boström, 2013 and L. fluvialis Alekseev, 1981 in having relatively short $(\mathrm{L}<1 \mathrm{~mm})$ and plump bodies $(\mathrm{a}<45)$, males without alveolar supplements and with continuous row of four tubular precloacal supplements, and females without tubular or alveolar supplements. Leptolaimus hadalis sp. nov. differs from L. gerlachi in shorter body length (587-741 versus 760-840 $\mu \mathrm{m}$ in L. gerlachi), slightly shorter cephalic setae ( 2 versus $3 \mu \mathrm{m}$ ), larger amphids (4-5 vs $3 \mu \mathrm{m}$ wide in males), amphids located further posteriorly (12-19 versus $11 \mu \mathrm{m}$ from anterior body extremity), first body pore located further posteriorly (30-38 versus $27 \mu \mathrm{m}$ from anterior body extremity), longer buccal cavity (20-29 versus $18 \mu \mathrm{m})$, slightly shorter spicules (22-24 versus $28 \mu \mathrm{m})$ and tubular supplements with dentate tips (versus bifid tips). Leptolaimus hadalis sp. nov. differs from L. praeclarus in longer body length (587-741 versus $442-518 \mu \mathrm{m}$ in L. praeclarus), longer tail ( $\mathrm{c}^{\prime}=5.0-8.7$ versus 3.03.7), amphids located further posteriorly (12-19 versus $9 \mu \mathrm{m}$ from anterior body extremity), first body pore located further posteriorly (30-38 versus $14 \mu \mathrm{m}$ from anterior body extremity), shape of gubernacular apophyses (bent distally versus straight) and tubular supplements with dentate tips (versus bifid tips). Leptolaimus hadalis sp. nov. differs from L. nonus in having amphids located further posteriorly (12-19 versus 8-10 $\mu \mathrm{m}$ from anterior extremity), first body pore

Peerj reviewing PDF | (2021:06:62838:1:0:NEW 26 Jul 2021) 
185 located further posteriorly (30-38 versus 17-29 $\mu \mathrm{m}$ from anterior body extremity), different 186 lateral alae shape (raised cuticle versus two incisures), and shape of gubernacular apophyses 187 (bent distally versus straight). Leptolaimus hadalis sp. nov. differs from L. fluvialis in having 188 amphids located further posteriorly (12-19 versus 5-12 $\mu \mathrm{m}$ from anterior body extremity), shape 189 of gubernacular apophyses (bent distally versus straight or slightly bent), and in the number of 190 precloacal supplements (four versus six supplements in original description). The two species 191 also differ in their type habitat, i.e., hadal trench versus lake sediments. The new species is also 192 similar to L. membranatus (Wieser, 1951) De Coninck, 1965 and L. septempapillatus Platt, 1973 193 in general body dimensions. Leptolaimus hadalis sp. nov. differs from L. membranatus in 194 having four precloacal supplements (versus five in L. membranatus) and absence of supplements 195 in females (versus one posterior tubular supplement in L. membranatus), and from $L$.

196 septempapillatus by the shorter body length (587-741 versus 762-965 $\mu \mathrm{m}$ in L. septempapillatus) 197 and the number of precloacal supplements (4 versus 7-8 in L. septempapillatus).

Family Camacolaimidae Micoletzky,1924

Genus Alaimella Cobb, 1920

201

202

203

204

205

206

207

208

209

210

211

212

Generic diagnosis: (from Holovachov (2014)) Annules with fine longitudinal striations. Lateral alae absent. Somatic sensilla present. Ocelli absent. Amphideal aperture ventrally unispiral. Buccal cavity narrow, undifferentiated; cheilostom without cuticularisations; gymnostom undeveloped; stegostom linear, its lining continuous with that of corpus. Pharynx gradually widening posteriorly into a glandular "cylindrus". Female reproductive system monodelphic-opisthodelphic. Tubular and alveolar supplements absent. Spinneret weakly cuticularized.

Type species: A. truncata Cobb, 1920

Remarks. The genus comprises three valid species. A key to species was provided by Tchesunov and Miljutin (2007).

Alaimella aff. cincta Cobb, 1920

Figs. 4-5, Table 1 
Material examined: Adult male (NIWA 154901), edge of Kermadec Trench, $6080 \mathrm{~m}$

214

215

216

217

218

219

220

221

222

223

224

225

226

227

228

229

230

231

232

233

234

235

236

237

238

239

240

241 water depth ( $R V$ Tangaroa voyage TAN1711, station $\left.55,32.1871^{\circ} \mathrm{S}, 176.5611^{\circ} \mathrm{W}\right)$, collected December 2017.

Measurements: See Table 1 for detailed measurements.

Description: Male. Body slender, tapering slightly towards both extremities. Cuticle with transverse annulations ca. $2.5 \mu \mathrm{m}$ apart, beginning slightly anterior to amphids to near tail tip, with fine longitudinal striations. Short, sparse lateral somatic setae present in pharyngeal region, slightly anterior and posterior to level of nerve ring. Cephalic region not set-off from rest of body but narrowing slightly just anterior to amphids. Lip region poorly developed; inner and outer labial sensilla not observed. Four cephalic setae, 1.1-1.3 cbd long. Amphideal fovea relatively large, ventral unispiral (cryptocircular), with cuticularized outline; amphideal aperture of same overall dimensions as fovea but with circular outline. Buccal cavity narrow, undifferentiated; cheilostom without cuticularisation, gymnostom undeveloped, stegostom linear, its lining continuous with that of corpus. Pharynx muscular in anterior and middle portions, narrow in middle portion and widening into an elongated, glandular posterior bulb; nucleus of dorsal pharyngeal gland visible. Nerve ring located mid-pharynx. Cardia well-developed, ca. $7 \mu \mathrm{m}$ wide and $10 \mu \mathrm{m}$ long, surrounded by intestine. Secretory-excretory system present; ventral gland relatively large, located well posterior to pharynx, pore not observed.

Reproductive system diorchic with both testes relatively small, directed anteriorly and outstretched; both testes located ventrally relative to intestine. Sperm cells globular, ca. $2.5 \times 2.5$ $\mu \mathrm{m}$. Spicules paired, symmetrical, slender, arcuate, 1.8 cloacal body diameters long; capitulum rounded, shaft and blade gradually tapering distally. Gubernaculum weakly developed, thin and plate-like. Precloacal supplements and ventral precloacal seta not observed. Tail conical, with pair of short lateral setae near two thirds of tail length from cloaca; three caudal glands present.

Remarks. The abyssal specimen agrees well with the original description of the species by Cobb (1920) based on specimens from Biscayne Bay, east coast of USA, including body length, cuticle ornamentation, size and shape of the amphids, length of cephalic setae, structure of pharynx, structure of male copulatory apparatus and tail. The abyssal specimen is also very similar to the description of L. cincta by Tchesunov \& Miljutin (2007) based on specimens from the subtidal 
242 zone of the White Sea, the only discrepancy being the larger amphids ( $9 \mu \mathrm{m}$ wide or 0.7 cbd

243 versus $5 \mu \mathrm{m}$ wide or $0.6 \mathrm{cbd}$ in the White Sea specimens).

244

245

246

247

248

249

250

251

252

253

254

255

256

257

258

259

260

261

262

263

264

265

266
Order Desmodorida De Coninck, 1965

Family Desmodoridae Filipjev, 1922

Genus Desmodora de Man, 1889

Generic diagnosis: (modified from Verschelde et al. (1998)) Cuticle without ridges or spines. Cephalic capsule either smooth or partly to entirely ornamented with structures resembling pores or small vacuoles, which have been shown by scanning electron microscopy to not be visible on the cuticle surface (e.g., Fadeeva et al. 2016); cephalic setae located either in the lip region or on main part of head capsule. Subcephalic setae sometimes present, when present few in number and mainly located posteriorly to amphideal fovea. Amphideal fovea cryptospiral or multispiral, seldom loop-shaped. Buccal cavity with large dorsal tooth and smaller subventral teeth. Pharynx with oval or circular posterior bulb. Spicules short, arcuate, with capitulum and velum. Precloacal supplements sometimes present, usually pore-like, seldom consisting of cuticular swellings or flaps. Tail usually conical, seldom conico-cylindrical.

Type species: D. communis (Bütschli, 1874)

Remarks. Leduc \& Zhao (2016) provided a list of all 35 valid species of the genus. The exact nature of the rods or vacuole structures observed in the cephalic capsule of some species is yet to be determined with certainty using electron microscopy; these structures may in fact be rods in the median layer of the cuticle.

Desmodora aff. pilosa Ditlevsen, 1926

= Desmodora gorbunovi Filipjev, 1946

= Desmodora gorbunovi perforata Filipjev, 1946

Figs. 6-8, Table 2 
Material examined: Adult male, adult female and juvenile (NIWA 154902) from edge

268

269

270

271

272

273

274

275

276

277

278

279

280

281

282

283

284

285

286

287

288

289

290

291

292

293

294

of Kermadec Trench, $6080 \mathrm{~m}$ water depth (RV Tangaroa voyage TAN1711, station 55, $\left.32.1871^{\circ} \mathrm{S}, 176.5611^{\circ} \mathrm{W}\right)$, collected December 2017.

Measurements: See Table 2 for detailed measurements.

Description: Male. Long cylindrical body, widest at level of pharynx, with slight golden-brown colouration throughout except for main portion of cephalic capsule which is strongly stained by Rose bengal; rounded anterior end and conical tail. Cuticle 3-4 $\mu \mathrm{m}$ thick, coarsely annulated with annulations slightly more widely spaced in pharyngeal region (ca. $1.5 \mu \mathrm{m}$ apart) than on rest of body (ca. $1.1 \mu \mathrm{m}$ apart). Eight longitudinal rows of somatic setae of variable length $(4-10 \mu \mathrm{m})$ along entire body length. Well-developed cephalic capsule, $44 \mu \mathrm{m}$ wide and $45 \mu \mathrm{m}$ long, consisting of two parts separated by a sutura: a lip portion with relatively thin cuticle and extendable anterior portion and a main region with thickened cuticle (up to $6 \mu \mathrm{m}$ thick) and comprising at least three quarters of cephalic capsule. Main portion of cephalic capsule with numerous, dense pores (or vacuoles) irregularly distributed except near base where pores are arranged in transverse rows and sometimes merging with each other; short, 3-4 $\mu \mathrm{m}$ long, sparse subcephalic setae present at level of amphids or slightly posterior. Six inner and six outer labial setae present on lip region; inner labial setae $3 \mu \mathrm{m}$ long, outer labial setae $4 \mu \mathrm{m}$ long. Four short cephalic setae present at level of sutura, $0.2 \mathrm{cbd}$ long. Amphideal fovea and aperture large, spiral with 1.5 turns and cuticularized outline, located on main portion of cephalic capsule; amphideal fovea slightly wider than amphideal aperture. Buccal cavity with large cuticularised dorsal tooth and two smaller ventrosublateral teeth; two lateral, transverse rows of small denticles also present. Cylindrical pharynx slightly swollen anteriorly and with oval posterior pharyngeal bulb. Secretory-excretory system not observed. Cardia $14 \mu \mathrm{m}$ long, partially surrounded by intestine. Reproductive system monorchic with outstretched testis located to the right of intestine. Mature sperm cells globular to oval-shaped, 16-19 × 10-11 $\mu \mathrm{m}$. Short, arcuate spicules with well-developed capitulum and tapering shaft and distal end; short, plate-like gubernaculum. Precloacal supplements and seta not observed. Conical tail with subventral and subdorsal rows of setae. Non-annulated tail tip without perforations. Caudal glands and spinneret present.

Peer) reviewing PDF | (2021:06:62838:1:0:NEW 26 Jul 2021) 
295 Female. Similar to males, but with smaller amphideal fovea with 1.25 turns and longer tail.

296 Reproductive system didelphic, amphidelphic with reflexed ovaries both located to the right of

297 intestine. Spermatheca not observed. Vulva located slightly posterior to mid-body. Proximal

298 portion of vagina heavily cuticularised; proximal portion of vagina surrounded by constrictor

299 muscle. Vaginal glands present.

300 Juvenile. Similar to female, but with shorter body, smaller cephalic capsule, slightly shorter

301 cephalic setae and slightly longer tail. Amphideal fovea with 1.5 turns.

302 Remarks. The abyssal specimens are broadly similar to previous descriptions of $D$. pilosa,

303 although some discrepancies can be observed (Table 3). The structure and shape of the cephalic 304 capsule, anterior sensilla, somatic setae, and amphideal fovea of the Kermadec Trench edge

305 female are all similar to the original description of the Northwest Atlantic female by Ditlevsen

306 (1926). However the Kermadec Trench edge female specimen is characterized by shorter body

307 (2776 versus $3000 \mu \mathrm{m})$, higher 'a' ratio (49 versus 30), shorter tail ( $\mathrm{c}^{\prime}=3.2$ versus 3.5), slightly

308 smaller amphideal fovea $(0.31$ versus $0.37 \mathrm{cbd})$ and cephalic capsule with numerous pores

309 (versus no pores). Unfortunately, Ditlevsen (1926) did not provide a description of the male, or

310 of the buccal armature, which limits morphological comparisons.

Desmodora gorbunovi Filipjev, 1946 and Desmodora gorbunovi perforata Filipjev, 1946 were synonymized with $D$. pilosa by Gerlach (1963). The former is characterized by cephalic capsule without pores whereas the latter is characterized by numerous pores in the cephalic capsule. Both of these are described by Filipjev (1946) as having a buccal cavity with a small dorsal tooth (although small ventrosublateral teeth may be present based on the drawings) without denticles. Clearly, Gerlach (1963) did not consider that the presence or absence of pores in the cephalic capsule as sufficient to justify separating the two populations into distinct species.

318 In his redescription of $D$. pilosa based on both males and female specimens from the Norwegian Sea, Jensen (1991) noted strong similarities between his specimens and Desmodora gorbunovi including the cephalic capsule with numerous pores, size and arrangement of anterior sensilla and somatic setae, structure of the amphideal fovea, and tail shape. Jensen's specimens, however, have a buccal cavity with a band of numerous denticles, whereas Filipjev's specimens do not have denticles. The descriptions of Filipjev (1946) and Jensen (1991) also show some inconsistencies in body dimensions and size of anterior sensilla and amphideal fovea (Table 3). 
325

326

327

328

329

330

331

332

333

334

335

336

337

338

339

340

341

342

343

344

345

346

347

348

349

350

351

352

353

The Kermadec Trench edge specimens differ from the descriptions of Jensen (1991) and Filipjev (1946) in buccal cavity armature, i.e., lateral transverse rows of denticles versus band of irregularly-arranged denticles along ventral sector in Jensen's description and no denticles in Filipjev's description. The Kermadec Trench edge specimens are also smaller (body length 2562-2776 versus $>2800 \mu \mathrm{m}$ ) than both descriptions and differ in a number of body dimensions and size of cephalic sensilla and amphideal fovea (Table 3).

\section{Discussion}

The present study provides some of the deepest species records for the genera Leptolaimus, Alaimella and Desmodora. Prior to this study, the deepest record of a Leptolaimus species was from the DISCOL nodule field in the abyssal East Pacific (L. formosus Bussau, 1993 at 4174 m; Miljutin et al. 2010), although unidentified Leptolaimus species have been found at low densities ( $\leq 1 \%$ of total nematode abundance) from as deep as $10811 \mathrm{~m}$ in the Tonga Trench (Leduc et al. 2016), $8189 \mathrm{~m}$ in the Puerto Rico Trench (Tietjen 1989) and $6300 \mathrm{~m}$ in the South Sandwich Trench (Vanhove et al. 2004). Leptolaimus hadalis sp. nov. was among the most common species observed in a survey of Kermadec Trench axis sites (Leduc \& Rowden 2018; referred to as "Leptolaimus D" therein). This species was the most abundant species in a core obtained at 8079 m water depth (21\% of total nematode abundance) and third most abundant species in a core obtained at $7132 \mathrm{~m}$ (6\% of total), while only one individual was found at $6096 \mathrm{~m}$ depth, and none at $9175 \mathrm{~m}$ depth (Leduc \& Rowden 2018). Leptolaimus hadalis sp. nov. was not found in cores obtained from the edge and deep axis of Tonga Trench (6250 and $10811 \mathrm{~m}$ depths; Leduc et al. 2016).

The rare marine genus Alaimella is seldom encountered in sediment samples. Prior to the present study, Alaimella had only been recorded from coastal locations (Cobb 1920, Raes et al. 2007, Tchesunov and Miljutin 2007) as well as from the Weddell sea (Alaimella sp. at unspecified depth between 200 and 2000 m; Vanhove et al. 1999). The record of Desmodora aff. pilosa at $6080 \mathrm{~m}$ depth is the deepest record of a Desmodora species to date. The previous deepest records were for D. nybelini Allgén, 1954 from the abyssal Atlantic at $4590 \mathrm{~m}$ depth and D. striatocephala Tchesunov, 2008 from the Southeast Atlantic at $5450 \mathrm{~m}$ depth. Unidentified 
354 Desmodora specimens have been found as deep as $6300 \mathrm{~m}$ in the South Sandwich Trench

355 (Vanhove et al. 2004).

356

357

358

359

360

361

362

363

364

365

366

367

368

369

370

371

372

373

374

375

376

377

378

379

380

381

382

It remains to be ascertained whether the Alaimella aff. cincta and Desmodora aff. pilosa specimens from Kermadec Trench are in fact new species. Because the morphology of Alaimella is relatively simple and given the relatively limited variation in morphological characters among species of the genus, molecular sequence data will be required to determine the identity of the Kermadec Trench edge population. It seems likely that the abyssal specimen described here represents a cryptic species given the distance from the type locality (Biscayne Bay, USA) and much greater water depth. Similarly, given the differences observed between the present description of Desmodora aff. pilosa and those of Ditlevsen (1926), Filipjev (1946) and Jensen (1991), it seems likely that the Kermadec Trench edge specimens represent a different species. However, this cannot be ascertained until further data are obtained from the type locality (upper continental slope of NW Atlantic) to determine the structure of the buccal cavity armature, presence or absence of pores in the cephalic capsule, and morphology of males. However, despite the uncertainty regarding the identity of the Kermadec Trench specimens, the detailed morphological descriptions provided here will enable comparisons to be conducted in future studies of deep-sea nematode communities.

\section{Acknowledgements}

Funding was provided by NIWA's Coasts and Oceans Centre Research Programme 'Marine Biological Resources' and the programme 'Impact of resource use on vulnerable deep-sea communities' (CO1X0906). I thank the co-voyage leaders Ronnie N. Glud and Ashley A. Rowden and science party of voyage TAN1711, and the officers and crew of RV Tangaroa, for their contribution to sample collection. The voyage was funded by European Research Council Advanced Grant (ERC adG 2014 grant agreement number 669947) as part of the HADES-ERC trench project, with additional support from various national research programmes. I also thank Tim Shank, principal investigator of the HADES project (HADal Ecosystem Studies, funded by the National Science Foundation (NSF-OCE1130712, 1130494 and 1131620), and to expedition leader Casey Machado, the officers, crew and scientific personnel of RV Thomas G.Thompson 
383 (voyage TN309), and ROV Nereus engineers and technicians. I am grateful to three anonymous

384 reviewers for providing constructive criticisms on the manuscript.

385

386

References

387

388

389

390

391

392

393

394

395

396

397

398

399

400

401

402

403

404

405

406

407

Alekseev VM. 1981. [Nematodes of the family Leptolaimidae (Nematoda Araeolaimida) from the brackish water of the South Sakhalin.] Svobodnozhivushchie i Fitopatogennye Nematody Fauny Dalnego Vostoka 3-7:64-67. [in Russian]

Allgén CA. 1954. Über zwei Tiefsee-Nematoden von der schwedischen Albatroß-Expedition 1948. Zoologischer Anzeiger 153:318-321.

Bussau C. 1993. Taxonomische und ökologische Untersuchungen an Nematoden des PeruBeckens. PhD dissertation, Kiel University. 625 pp.

Bütschli O. 1874. Zur Kenntniss der freilebenden Nematoden, insbesondere der des Kieler Hafens. Abhandlungen, Herausgegeben von der Senckenbergischen Naturforschenden Gesellschaft 9:236-292.

Cobb NA. 1920. One hundred new nemas (type species of 100 new genera). Contributions to a Science of Nematology 9:217-343

Coomans A. 1979. Addendum I. A proposal for a more precise terminology of the body regions in the nematode. Annales de la Societee Royale Zoologique de Belgique 108:115-117.

De Coninck, L.A. 1965. Systématique des Nématodes. Pp.586-31 in: Grassé, P.P. (Ed) Traité de Zoologie: Anatomie, Systématique, Biologie. Nemathelminthes (Nematodes). Masson et Cie, Paris. 731 pp.

de Man JG. 1876. Onderzoekingen over vrij in de aarde levende Nematoden. Tijdschrift Nederlandsche Dierkundig Vereeiging 2:78-196

de Man JG. 1889. Espèces et genres nouveaux de Nématodes libres de la mer du Nord et de la Manche. Mémoires de la Société Zoologique de France 2:1-10 
408 Ditlevsen H. 1926. The Danish Ingolf Expedition Volume IV. 6. Free-living nematodes.

409 Copenhagen, Bianco Luno. 42 pp.

410

411

412

413

414

415

416

417

418

419

420

421

422

423

424

425

426

427

428

429

430

431

Fadeeva N, Mordukhovich V, Zograf J. 2016. Free-living marine nematodes of Desmodorella and Zalonema (Nematoda: Desmodoridae) with description of two new species from the deep sea of the North Western Pacific. Zootaxa 4175:501-520.

Filipjev IN. 1922. New data on free nematodes of the Black Sea (Novye Dannye o Svobodnykh Nematodakh Chernogo Moria). Trudy Stavropol'skogo Sel'skokhoziaistvennogo Instituta 1:13-184.

Filipjev IN. 1946. Free-living Nematodes from the Northern Arctic Ocean. Trudy, Dreifuiushchaia ekspeditsiia Glavsevmorputi na ledokol'nom parokhode "G. Sedov" 19371940 3:158-184.

Gadea E. 1973. Sobre la filogenia interna de los nematodos. Publicación del Instituto de Biologiá Aplicada 54:87-92

Gerlach SA. 1963. Freilebende Meeresnematoden von den Malediven II. Kieler Meeresforschung 19:67-103.

Holovachov O., Boström S. 2013. Swedish Plectida (Nematoda). Part 4. The genus Leptolaimus de Man, 1876. Zootaxa 3739:1-99

Holovachov O. 2014. Order Plectida Gadea, 1973. Pp. 487-535 in: Schmidt-Rhaesa A. ed. Handbook of Zoology Volume 2: Nematoda. Hamburg: De Gruyter, xv + 759 pp.

Jensen P. 1991. Nine new and less known nematode species from the deep-sea benthos of the Norwegian Sea. Hydrobiologia 222:57-76.

Leduc D, Zhao ZQ 2016. Morphological and molecular characterization of new Acanthopharynx and Desmodora species (Nematoda: Desmodorinae) from intertidal sediments of New zealand. Nematology 18:905-924. 
432 Leduc D, Rowden AA, Glud RN, Wenzhofer F, Kitazato H, Clark MR. 2016. Comparison 433 between infaunal communities of the deep floor and edge of the Tonga Trench: Possible 434 effects of differences in organic matter supply. Deep-Sea Research I 116:264-275.

435 436

437

438

439

440

441

442

443

444

445

446

447

448

449

450

451

452

453 454

Leduc D, Rowden AA. 2018. Nematode communities in sediments of the Kermadec Trench, Southwest Pacific Ocean. Deep-Sea Research I 134:23-31.

Leduc D. 2020. Two new nematode species (Plectida: Leptolaimidae, Rhadinematidae) from Chatham Rise, New Zealand. PeerJ 8:e9923

Micoletzky H. 1924. Letzter bericht über freilebende nematoden aus Suez. Sitzungsberichten der Akademie der Wissenschaften in Wien, Mathem-naturw 133: 137-179.

Miljutin DM, Gad G, Miljutina MM, Mokievsky VO, Fonseca-Genevois V, Esteves AM. 2010. The state of knowledge on deep-sea nematode taxonomy: how many valid species are known down there? Marine Biodiversity 40:143-159.

Murphy DG. 1966. An initial report on a collection of Chilean marine nematodes. Mitteilungen aus dem Hamburgischen zoologische Museum und Institut 63:29-50.

Örley L. 1880. Monographie der Anguilluliden. Természetrajzi Füzetek 4:1-165.

Qiao C., Jia S., Huang Y. 2020. Leptolaimus holovachovi sp. nov. (Nematoda) from Shenzhen Mangrove Nature Reserve, Shenzhen, South China. Journal of Oceanology and Limnology 38:1907-1913.

Raes M, De Troch M, Ndaro SGM, Muthumbi A, Guilini K, Vanreusel A. 2007. The structuring role of microhabitat type in coral degradation zones: a case study with marine nematodes from Kenya and Zanzibar. Coral Reefs 26:113-126.

Somerfield PJ, Warwick RM. 1996. Meiofauna in Marine Pollution Monitoring Programmes: a Laboratory Manual. Lowestoft: Ministry of Agriculture, Fisheries and Food. 
455 Tchesunov AV, Miljutin DM 2007. Free-living nematodes of the genus Alaimella Cobb 1920 456 (Nematoda: Leptolaimidae): A description of A. macramphis sp. n. from the White Sea and a 457 revision of the genus. Russian Journal of Marine Biology 33:92-97.

458 459

460 461

462 463

464 465

466

467

468

469

470

471

472

473

474

475

476

477

478

Tchesunov AV. 2008. Three new species of free-living nematodes from the South-East Atlantic abyss (DIVA I Expedition). Zootaxa 1866:151v174.

Tchesunov AV. 2015. Free-living nematode species (Nematoda) dwelling in hydrothermal sites of the North Mid-Atlantic Ridge. Helgoland Marine Research 69:343-384

Tietjen JH. 1989. Ecology of deep-sea nematodes from the Puerto Rico Trench area and Hatteras Abyssal Plain. Deep-Sea Research 36:1579-1594.

Timm RW. 1961. The marine nematodes of the Bay of Bengal. Proceedings of the Pakistan Academy of Sciences 1:1-88.

Vanhove S, Arntz W, Vincx M. 1999. Comparative study of the nematode communities of the southeastern Weddell Sea shelf and slope (Antarctica). Marine Ecology Progress Series 181:237-256.

Vanhove S, Vermeeren H, Vanreusel A. 2004. Meiofauna towards the South Sandwich Trench (750-6300 m), focus on nematodes. Deep-Sea Research II 51:1665-1687.

Verschelde D, Gourbault N, Vincx M. 1998. Revison of Desmodora with descriptions of new desmodorids (Nematoda) from hydrothermal vents of the Pacific. Journal of the Marine Biological Association of the United Kingdom 78:75-112.

Wieser W. 1951. Untersuchungen über die algenbewohnende Mikrofauna mariner Hartböden. I. Zur Ökologie und Systematik der Nematodenfauna von Plymouth. Österreichische Zoologische Zeitschrift 3:425-480.

Zeppilli D, Leduc D, Fontanier C, Fontaneto D, Fuchs S, Gooday AJ, et al. 2018. Characteristics of meiofauna in extreme marine ecosystems: a review. Marine Biodiversity 48:35-71. 


\section{Figure captions}

481 Figure 1. Leptolaimus hadalis sp. nov. A. Anterior body region of male; B. male cephalic 482 region; C. female cephalic region; D. female posterior body region; E. male posterior body 483 region. Scale bar: $\mathrm{A}=40 \mu \mathrm{m}, \mathrm{B} \& \mathrm{C}=25 \mu \mathrm{m}, \mathrm{D}=42 \mu \mathrm{m}, \mathrm{E}=35 \mu \mathrm{m}$.

484 Figure 2. Leptolaimus hadalis sp. nov. A. Entire male; B. entire female. Scale bar $=100 \mu \mathrm{m}$.

485 Figure 3. Leptolaimus hadalis sp. nov. Light micrographs of holotype A- C. Anterior body 486 region showing cuticle ornamentation, amphid, first body pore and buccal cavity; D. posterior 487 pharyngeal region, cardia and intestine; E. mid-body cuticle with lateral ala; F. precloacal 488 supplement; G. posterior body region with copulatory apparatus. Scale bar: A - C $=10 \mu \mathrm{m}, \mathrm{D}-$ $489 \mathrm{G}=14 \mu \mathrm{m}$.

490 Figure 4. Alaimella aff. cincta Male A. Anterior body region; B. cephalic region; C. posterior 491 body region; $\mathrm{D}$. entire male. Scale bar: $\mathrm{A}=40 \mu \mathrm{m}, \mathrm{B}=12 \mu \mathrm{m}, \mathrm{C}=28 \mu \mathrm{m}, \mathrm{D}=125 \mu \mathrm{m}$.

492 Figure 5. Alaimella aff. cincta Light micrographs of male A \& B. Cephalic region; C. cuticle of 493 mid-body region; D. Tail tip. Scale bar $=10 \mu \mathrm{m}$.

Figure 6. Desmodora aff. pilosa A. Anterior body region of female; B. male cephalic region; C. female cephalic region; D \& E. juvenile cephalic region; F. female posterior body region; G. male posterior body region. Scale bar: $\mathrm{A}=60 \mu \mathrm{m}, \mathrm{B}-\mathrm{E}=25 \mu \mathrm{m}, \mathrm{F} \& \mathrm{G}=45 \mu \mathrm{m}$.

497 Figure 7. Desmodora aff. pilosa Entire male. Scale bar $=500 \mu \mathrm{m}$.

498 Figure 8. Desmodora aff. pilosa Light micrographs A - C. Juvenile cephalic region; D. male 499 cephalic region; E \& F. female cephalic region. Scale bar $=10 \mu \mathrm{m}$. 


\section{Table $\mathbf{1}$ (on next page)}

Morphometrics $(\mu \mathrm{m})$ of Leptolaimus hadalis sp. nov. and Alaimella aff. cincta from Kermadec Trench 
Table 1. Morphometrics ( $\mu \mathrm{m})$ of Leptolaimus hadalis sp. nov. and Alaimella aff. cincta from Kermadec Trench.

\begin{tabular}{|c|c|c|c|c|c|c|c|c|}
\hline & \multicolumn{4}{|c|}{$\begin{array}{l}\text { Leptolaimus hadalis sp. nov. } \\
\text { Males }\end{array}$} & \multicolumn{3}{|l|}{ Females } & \multirow[t]{2}{*}{$\begin{array}{l}\text { Alaimella aff. cincta } \\
\text { Male }\end{array}$} \\
\hline & Holotype & Paratype 1 & Paratype 2 & Paratype 3 & Paratype 1 & Paratype 2 & Paratype 3 & \\
\hline $\mathrm{L}$ & 638 & 612 & 650 & 741 & 681 & 587 & 628 & 1508 \\
\hline $\mathrm{a}$ & 34 & 32 & 34 & 37 & 28 & 27 & 30 & 52 \\
\hline b & 5 & 5 & 5 & 5 & 5 & 5 & 5 & 7 \\
\hline c & 6 & 7 & 6 & 7 & 6 & 6 & 6 & 11 \\
\hline$c^{\prime}$ & 6.0 & 5.0 & 6.3 & 5.6 & 7.9 & 7.8 & 8.7 & 6.2 \\
\hline Head diam. at cephalic setae & 5 & 4 & 5 & 5 & 5 & 4 & 4 & 9 \\
\hline Head diam. at amphids & 8 & 8 & 8 & 9 & 9 & 8 & 8 & 13 \\
\hline Length of cephalic setae & 2 & 2 & 2 & 2 & 2 & 2 & 2 & $10-12$ \\
\hline Amphid height & 6 & 5 & 5 & 5 & 4 & 4 & 4 & 9 \\
\hline Amphid width & 4 & 5 & 5 & 5 & 4 & 3 & 4 & 9 \\
\hline Amphid width/cbd (\%) & 50 & 63 & 63 & 56 & 44 & 38 & 50 & 69 \\
\hline Amphid from anterior end & 14 & 14 & 15 & 16 & 19 & 12 & 15 & 4 \\
\hline First body pore from anterior & 33 & 34 & 31 & 38 & 37 & 30 & 34 & - \\
\hline Lateral alae from anterior & 49 & 49 & 41 & 71 & 64 & 54 & 58 & - \\
\hline Buccal cavity length & 27 & 20 & 24 & 26 & 29 & 23 & 25 & - \\
\hline Nerve ring from anterior end & 84 & 79 & 80 & 86 & 92 & 74 & 82 & 109 \\
\hline Nerve ring cbd & 18 & 17 & 17 & 19 & 19 & 17 & 18 & 26 \\
\hline Pharynx length & 134 & 124 & 127 & 138 & 140 & 112 & 132 & 221 \\
\hline Pharyngeal bulb diam. & 10 & 10 & 10 & 10 & 10 & 10 & 10 & 12 \\
\hline Pharynx cbd & 19 & 18 & 19 & 20 & 20 & 19 & 19 & 27 \\
\hline Max. body diam. & 19 & 19 & 19 & 20 & 24 & 22 & 21 & 29 \\
\hline Spicule length & 24 & 24 & 24 & 22 & - & - & - & 39 \\
\hline Gubernaculum length & 9 & 11 & 8 & 7 & - & - & - & 11 \\
\hline Cloacal/anal body diam. & 17 & 18 & 16 & 20 & 14 & 13 & 12 & 22 \\
\hline Tail length & 102 & 90 & 101 & 111 & 110 & 101 & 104 & 137 \\
\hline $\mathrm{V}$ & - & - & - & - & 348 & 282 & 308 & - \\
\hline$\% \mathrm{~V}$ & - & - & - & - & 51 & 48 & 49 & - \\
\hline Vulval body diam. & - & - & - & - & 24 & 22 & 20 & - \\
\hline
\end{tabular}




\section{Table 2 (on next page)}

Morphometrics $(\mu \mathrm{m})$ of Desmodora aff. pilosa from the edge of Kermadec Trench. 
2 Table 2. Morphometrics ( $\mu \mathrm{m})$ of Desmodora aff. pilosa from the edge of Kermadec Trench. 3

\begin{tabular}{llll}
\hline Species & \multicolumn{3}{l}{ Desmodora } \\
& Male & Filosa & \\
& 2562 & 2776 & 2178 \\
L & 43 & 49 & 46 \\
a & 9 & 11 & 10 \\
b & 22 & 21 & 16 \\
c & 2.3 & 3.2 & 3.8 \\
c' $^{\prime}$ & 28 & 32 & 28 \\
Head diam. at cephalic setae & 39 & 42 & 34 \\
Head diam. at amphids & $3-4$ & $3-6$ & - \\
Length of sub-cephalic setae & 5 & 4 & 3 \\
Length of cephalic setae & 24 & 16 & 13 \\
Amphid height & 19 & 13 & 13 \\
Amphid width & 49 & 31 & 38 \\
Amphid width/cbd (\%) & 7 & 11 & 10 \\
Amphid from anterior end & 176 & 136 & 131 \\
Nerve ring from anterior end & 55 & 58 & 52 \\
Nerve ring cbd & 278 & 243 & 210 \\
Pharynx length & 61 & 70 & 60 \\
Pharyngeal bulb length & 38 & 43 & 39 \\
Pharyngeal bulb diam. & 54 & 56 & 53 \\
Pharynx cbd & 60 & 57 & 47 \\
Max. body diam. & 75 & - & - \\
Spicule length & 30 & - & - \\
Gubernaculum length & 51 & 41 & 36 \\
Cloacal/anal body diam. & 118 & 132 & 137 \\
Tail length & - & 1505 & - \\
V & - & 54 & - \\
\%V & - & 57 & - \\
Vulval body diam. & & & \\
\hline & & & \\
\hline
\end{tabular}




\section{Table 3 (on next page)}

Comparison of morphometric data of Desmodora pilosa Ditlevsen, 1926 from the literature. Values and character states for males and females shown on grey background do not overlap with the Kermadec Trench edge (SW Pacific) specimens.

ND = no data; *estimated from figure; **morphometric data of females not provided; ***Desmodora gorbunovi Filipjev, 1946 and D. gorbunovi perforata Filipjev, 1946 were synonymised with $D$. pilosa by Gerlach (1963); ${ }^{*}$ pores present in $D$. gorbunovi perforata but absent in D. gorbunovi 
Table 3. Comparison of morphometric data of Desmodora pilosa Ditlevsen, 1926 from the literature. Values and character states for males and females shown on grey background do not overlap with the Kermadec Trench edge (SWPacific) specimens.

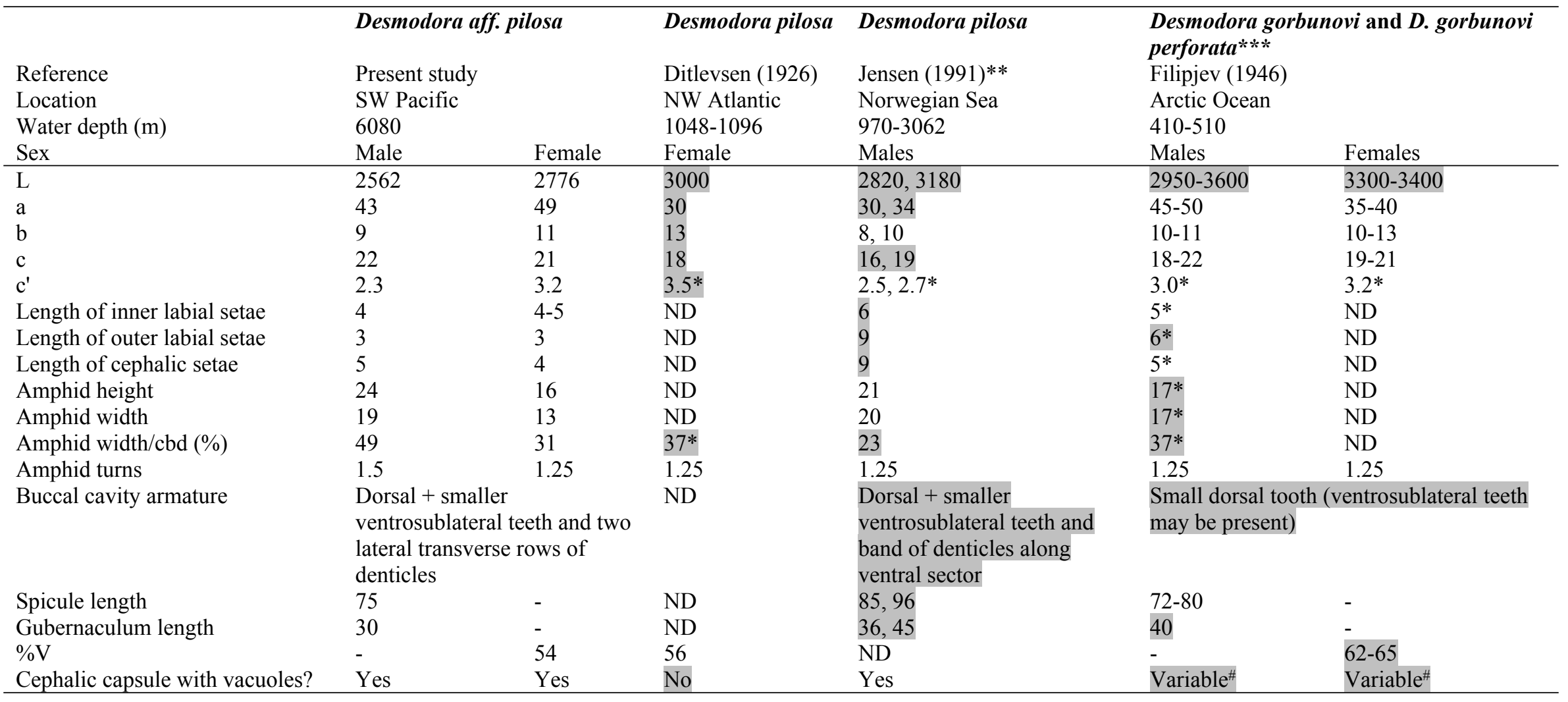

5

*estimated from figure

**morphometric data of females not provided

***Desmodora gorbunovi Filipjev, 1946 and D. gorbunovi perforata Filipjev, 1946 were synonymised with $D$. pilosa by Gerlach (1963).

11 "Pores present in D. gorbunovi perforata but absent in D. gorbunovi 


\section{Figure 1}

Leptolaimus hadalis sp. nov.

(A) Anterior body region of male. (B) Male cephalic region. (C) Female cephalic region. (D)

Female posterior body region. (E) Male posterior body region. Scale bar: $\mathrm{A}=40 \mu \mathrm{m}, \mathrm{B} \& \mathrm{C}=$ $25 \mu \mathrm{m}, \mathrm{D}=42 \mu \mathrm{m}, \mathrm{E}=35 \mu \mathrm{m}$. 


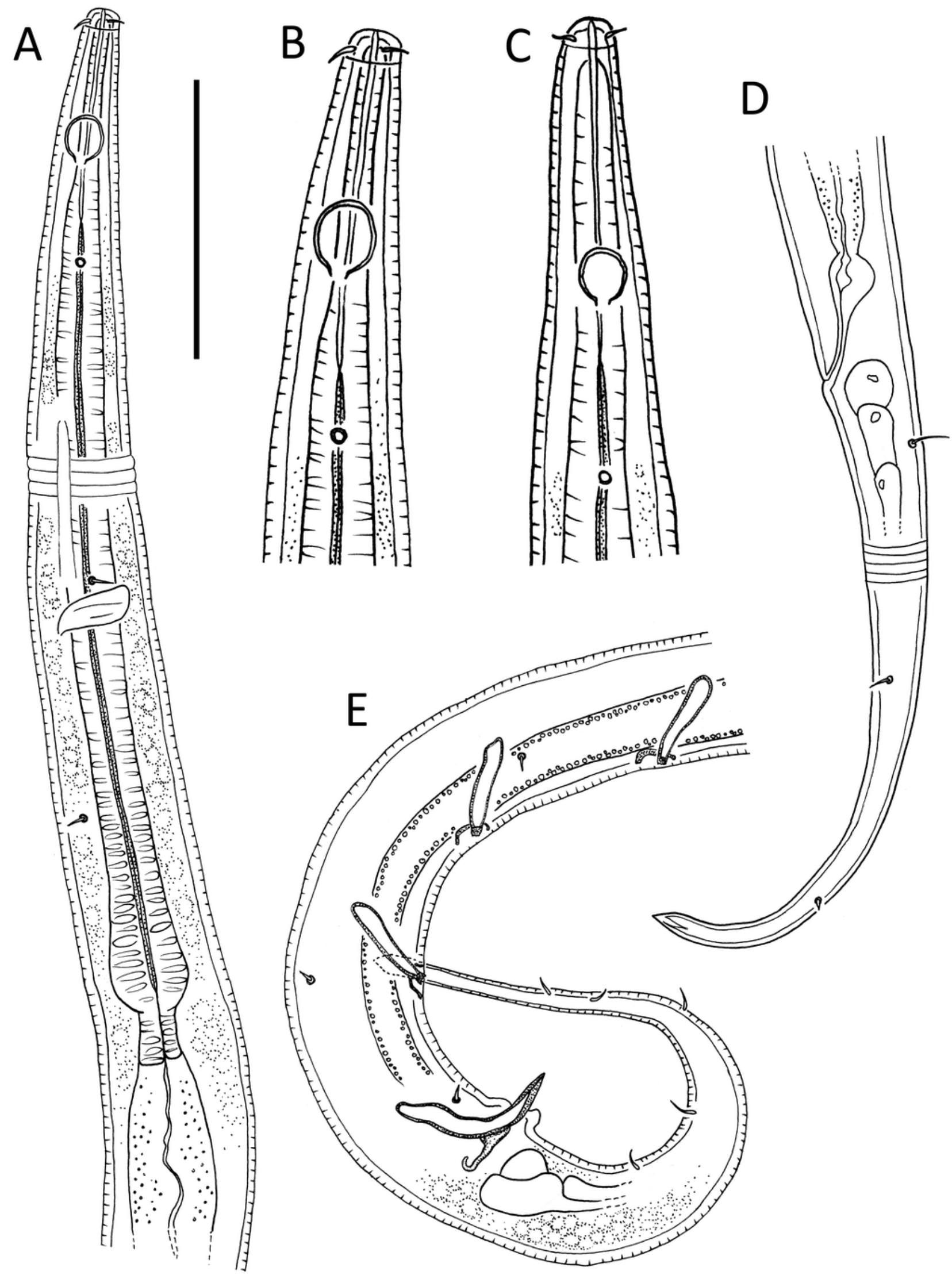


Figure 2

Leptolaimus hadalis sp. nov.

(A) Entire male. (B) Entire female. Scale bar $=100 \mu \mathrm{m}$. 


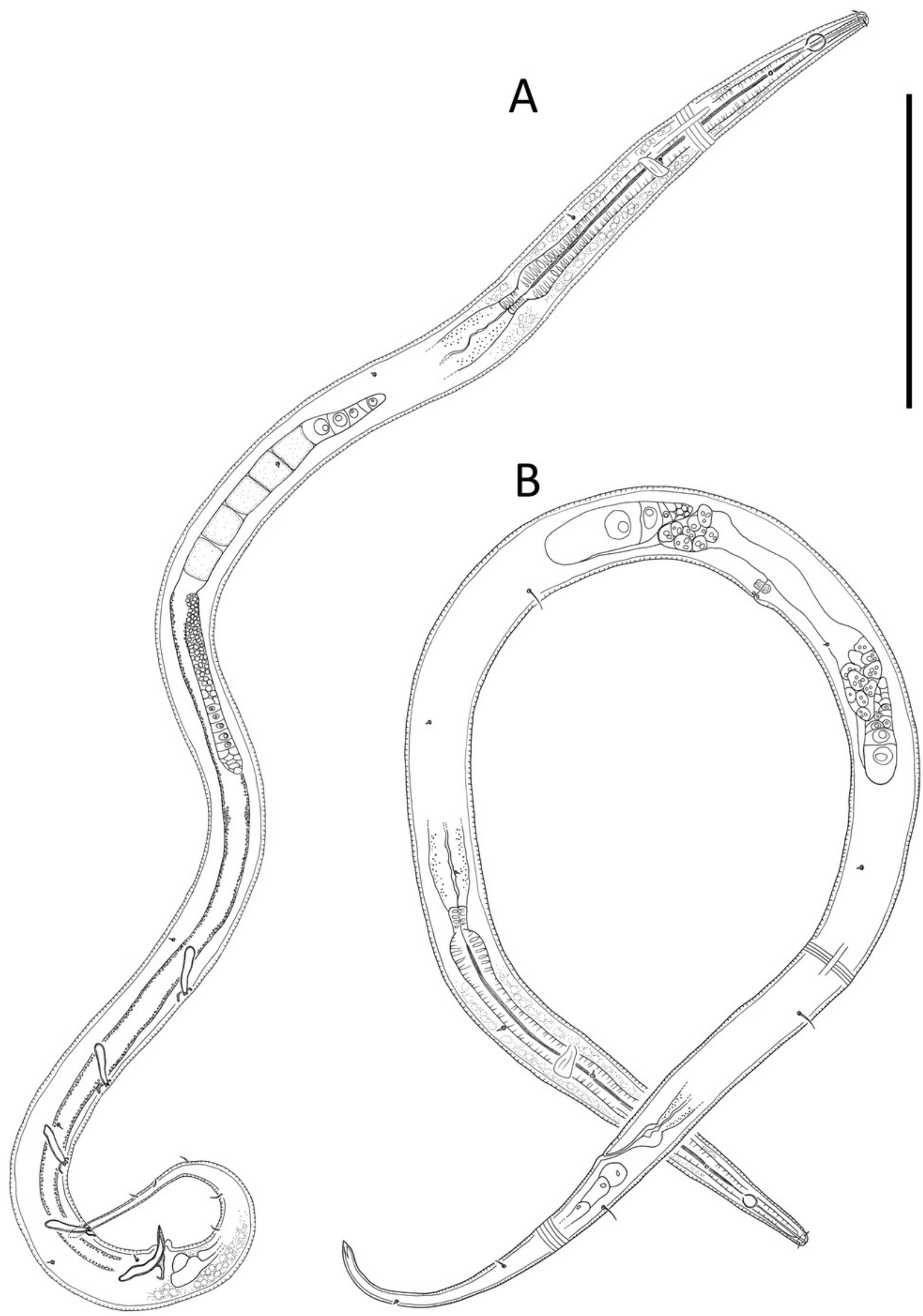

Peer] reviewing PDF | (2021:06:62838:1:0:NEW 26 Jul 2021) 


\section{Figure 3}

Leptolaimus hadalis sp. nov. Light micrographs of holotype

(A - C) Anterior body region showing cuticle ornamentation, amphid, first body pore and buccal cavity. (D) Posterior pharyngeal region, cardia and intestine. (E) Mid-body cuticle with lateral ala. (F) Precloacal supplement. (G) Posterior body region with copulatory apparatus.

Scale bar: A - C $=10 \mu \mathrm{m}, \mathrm{D}-\mathrm{G}=14 \mu \mathrm{m}$. 

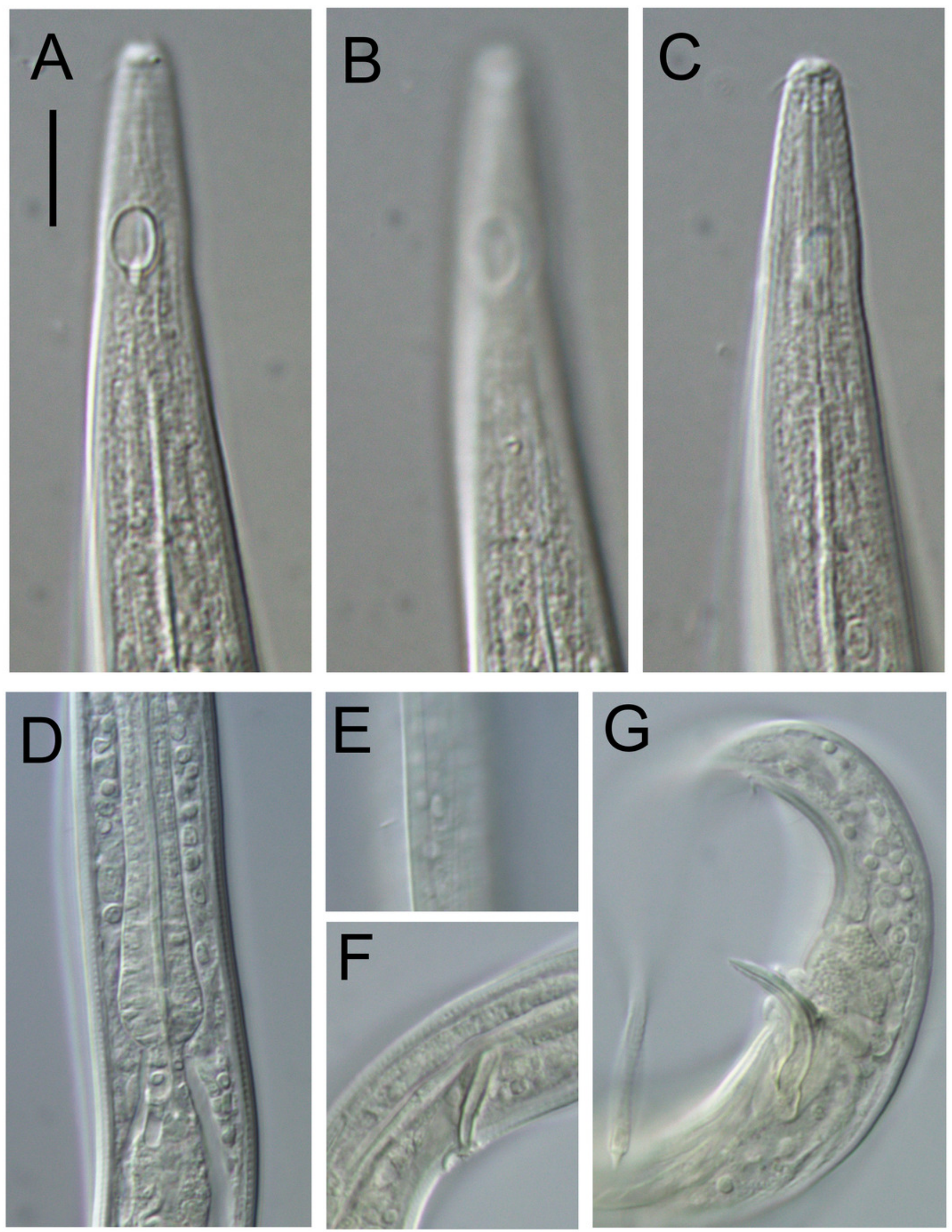
Figure 4

Alaimella aff. cincta male.

(A) Anterior body region. (B) Cephalic region. (C) Posterior body region. (D) Entire male. Scale bar: $\mathrm{A}=40 \mu \mathrm{m}, \mathrm{B}=12 \mu \mathrm{m}, \mathrm{C}=28 \mu \mathrm{m}, \mathrm{D}=125 \mu \mathrm{m}$. 
A

A

復
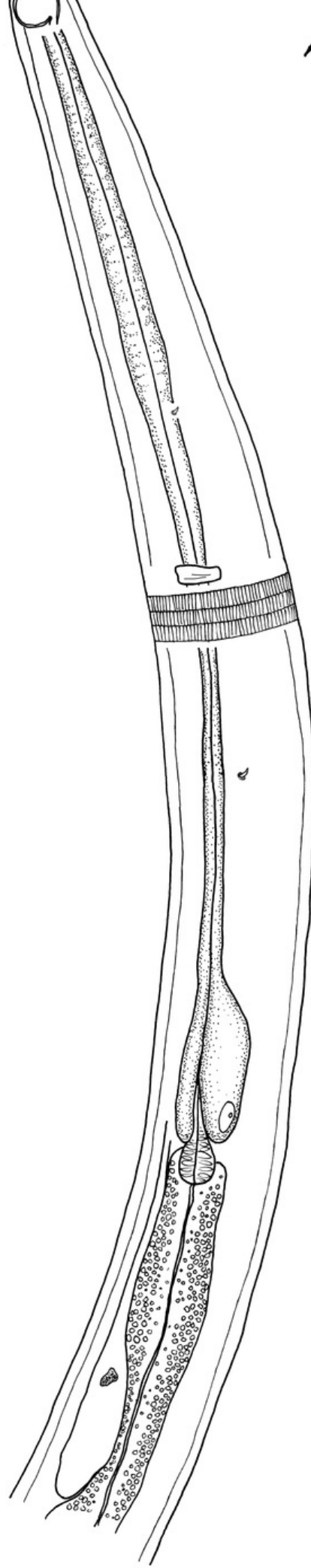

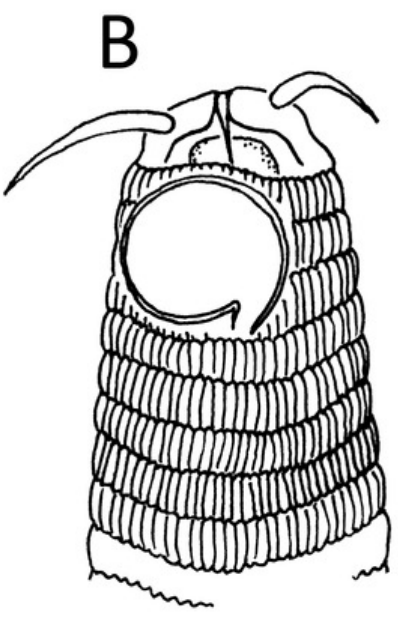

D
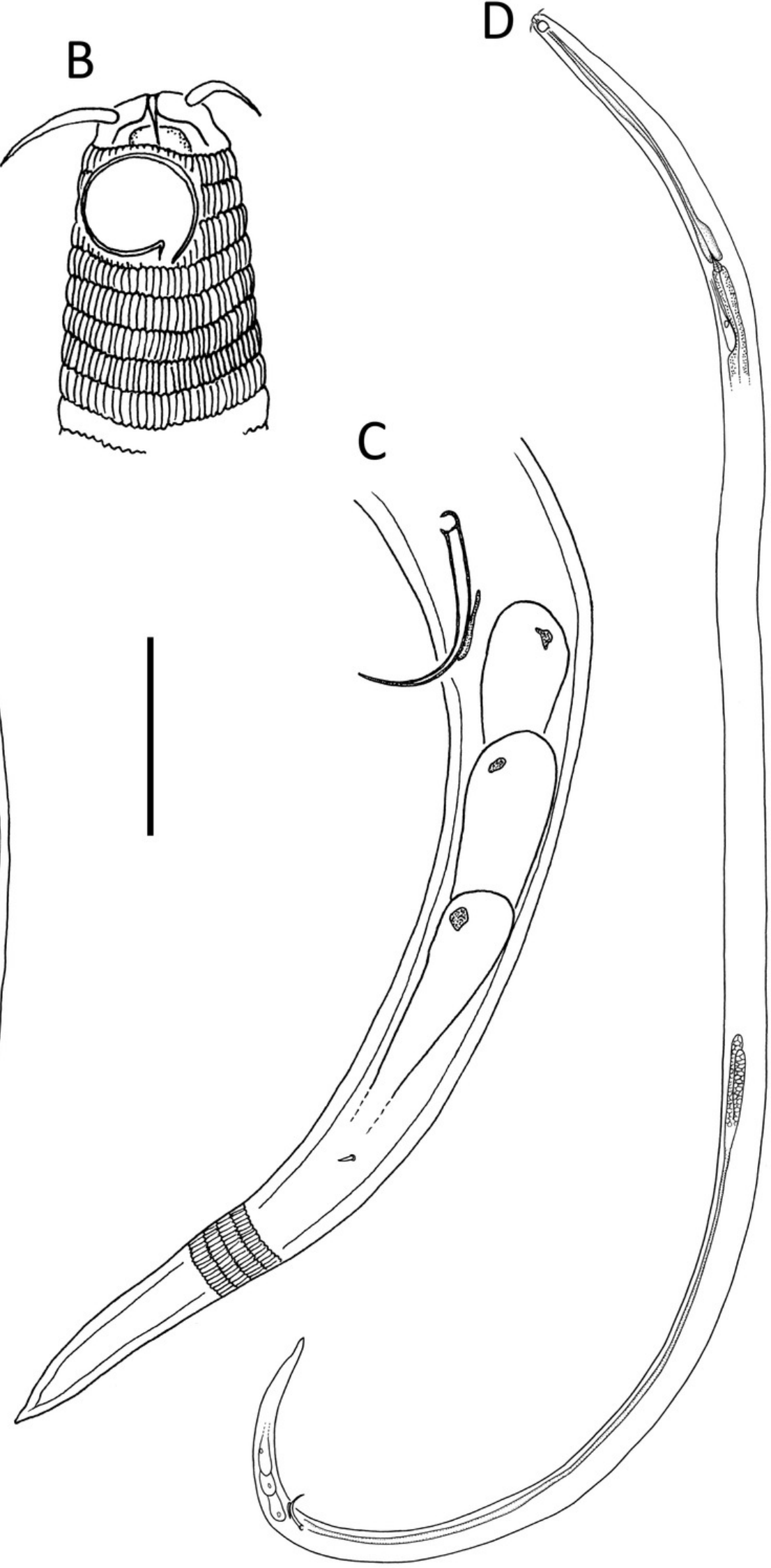

Peer) reviewing PDF | (2021:06:62838:1:0:NEW 26 Jul 2021) 
Figure 5

Alaimella aff. cincta Light micrographs of male

(A \& B) Cephalic region. (C) Cuticle of mid-body region. (D) Tail tip. Scale bar $=10 \mu \mathrm{m}$. 

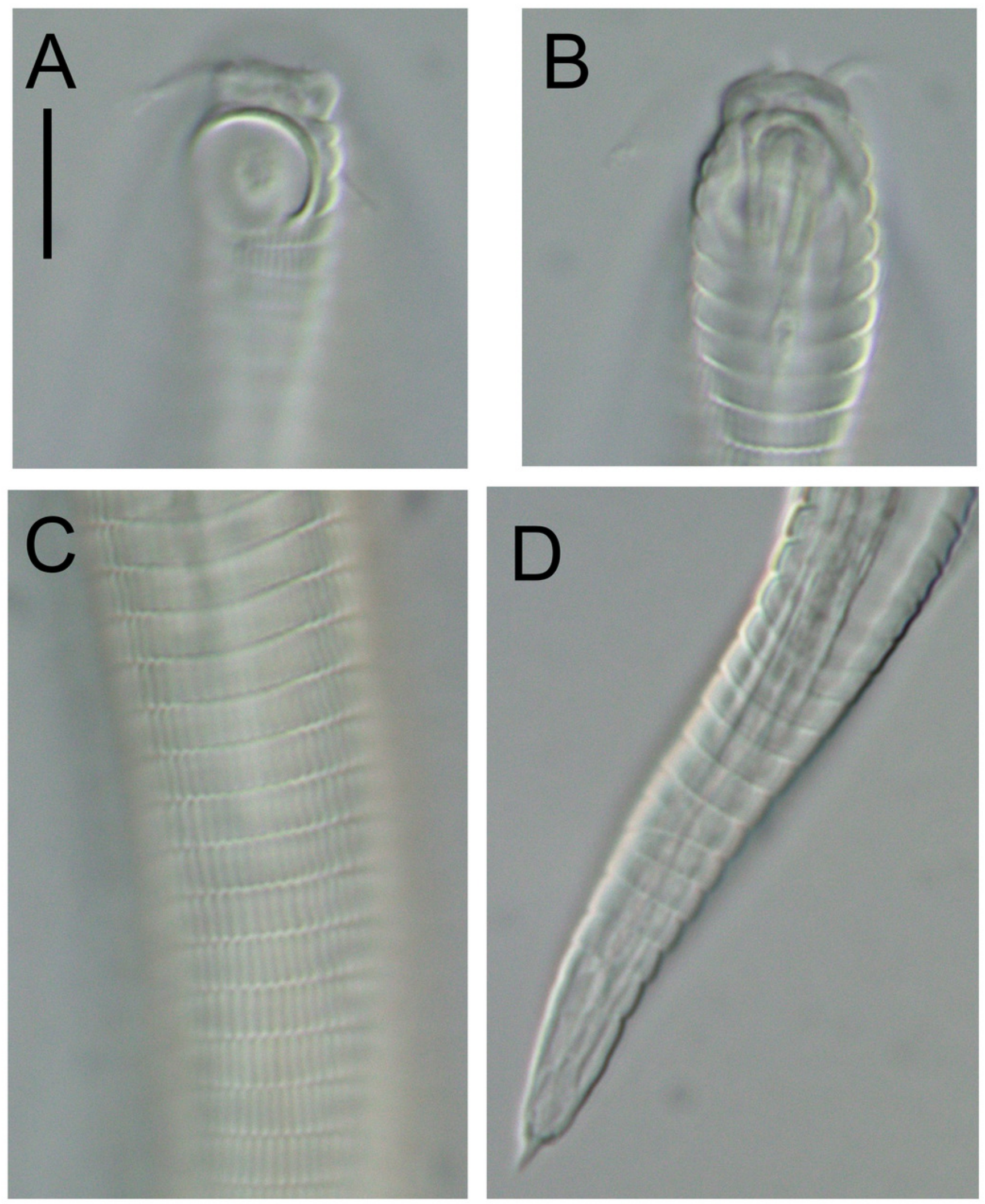
Figure 6

Desmodora aff. pilosa

(A) Anterior body region of female. (B) Male cephalic region. (C) Female cephalic region. (D \&

E) Juvenile cephalic region. (F) Female posterior body region. (G) male posterior body region.

Scale bar: $A=60 \mu \mathrm{m}, \mathrm{B}-\mathrm{E}=25 \mu \mathrm{m}, \mathrm{F} \& \mathrm{G}=45 \mu \mathrm{m}$. 


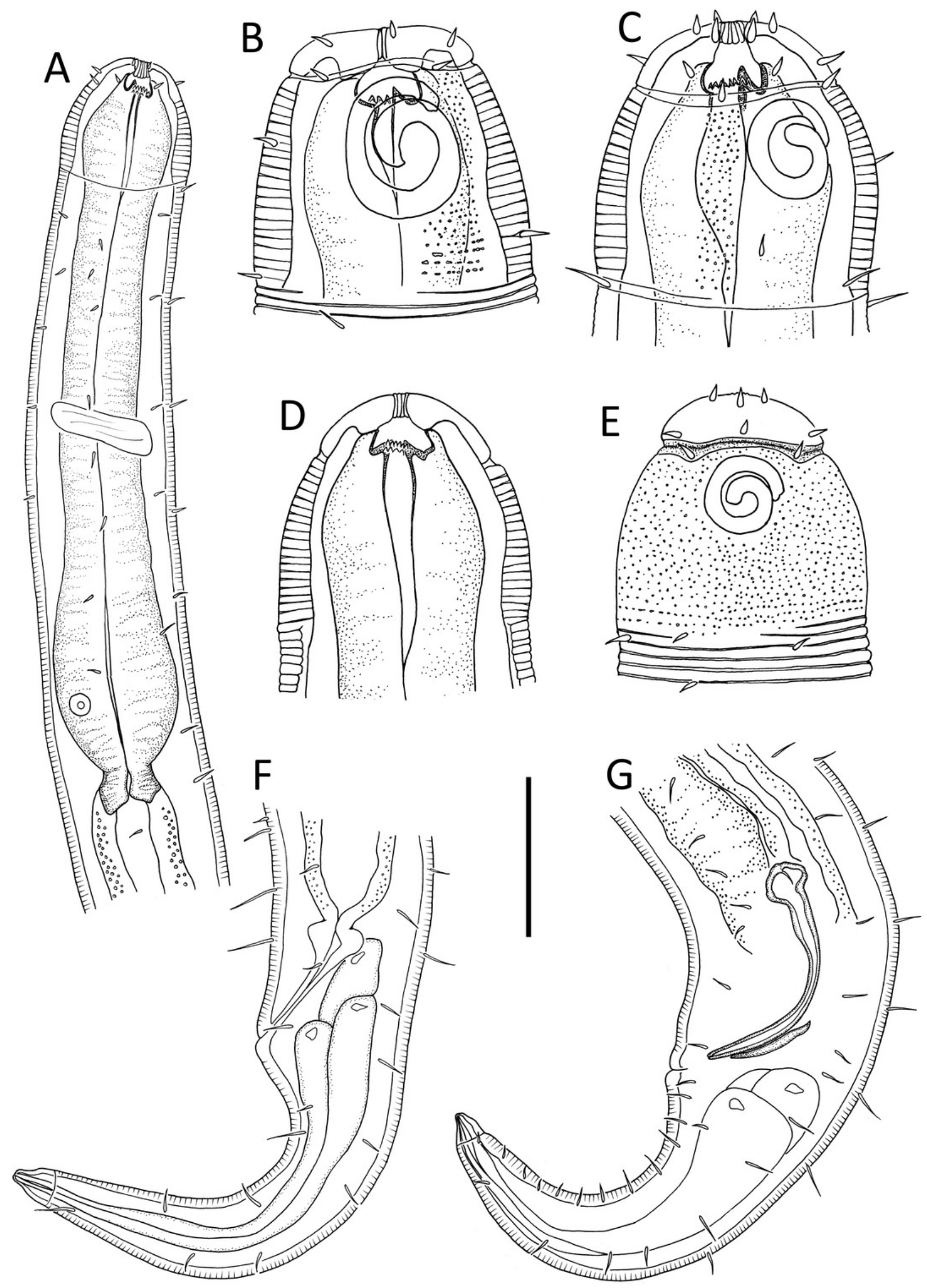

PeerJ reviewing PDF | (2021:06:62838:1:0:NEW 26 Jul 2021) 
Figure 7

Desmodora aff. pilosa Entire male.

Scale bar $=500 \mu \mathrm{m}$. 


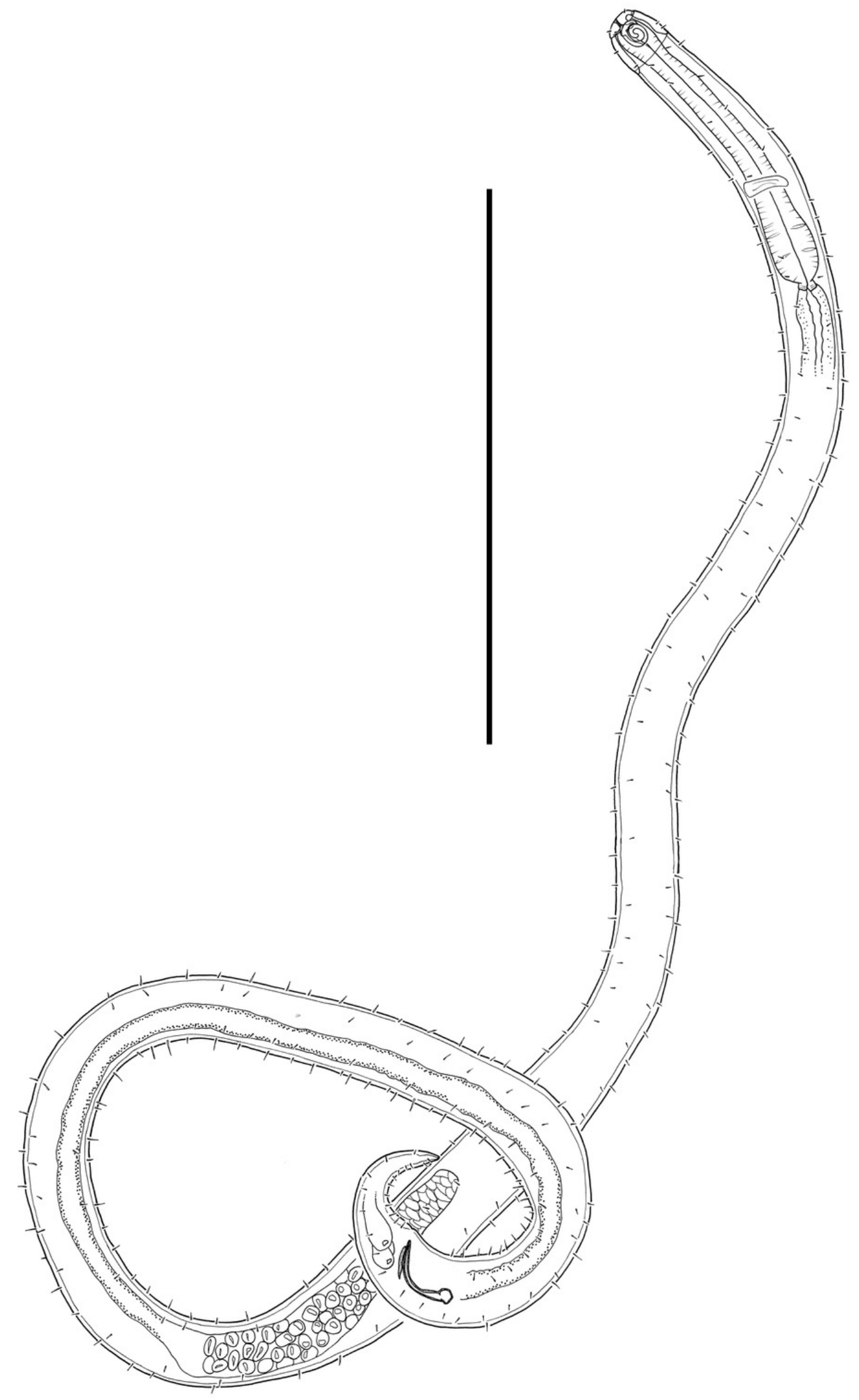


Figure 8

Desmodora aff. pilosa Light micrographs.

$(A, B \& C)$ Juvenile cephalic region. (D) Male cephalic region. (E \& F) Female cephalic region.

Scale bar $=10 \mu \mathrm{m}$ 

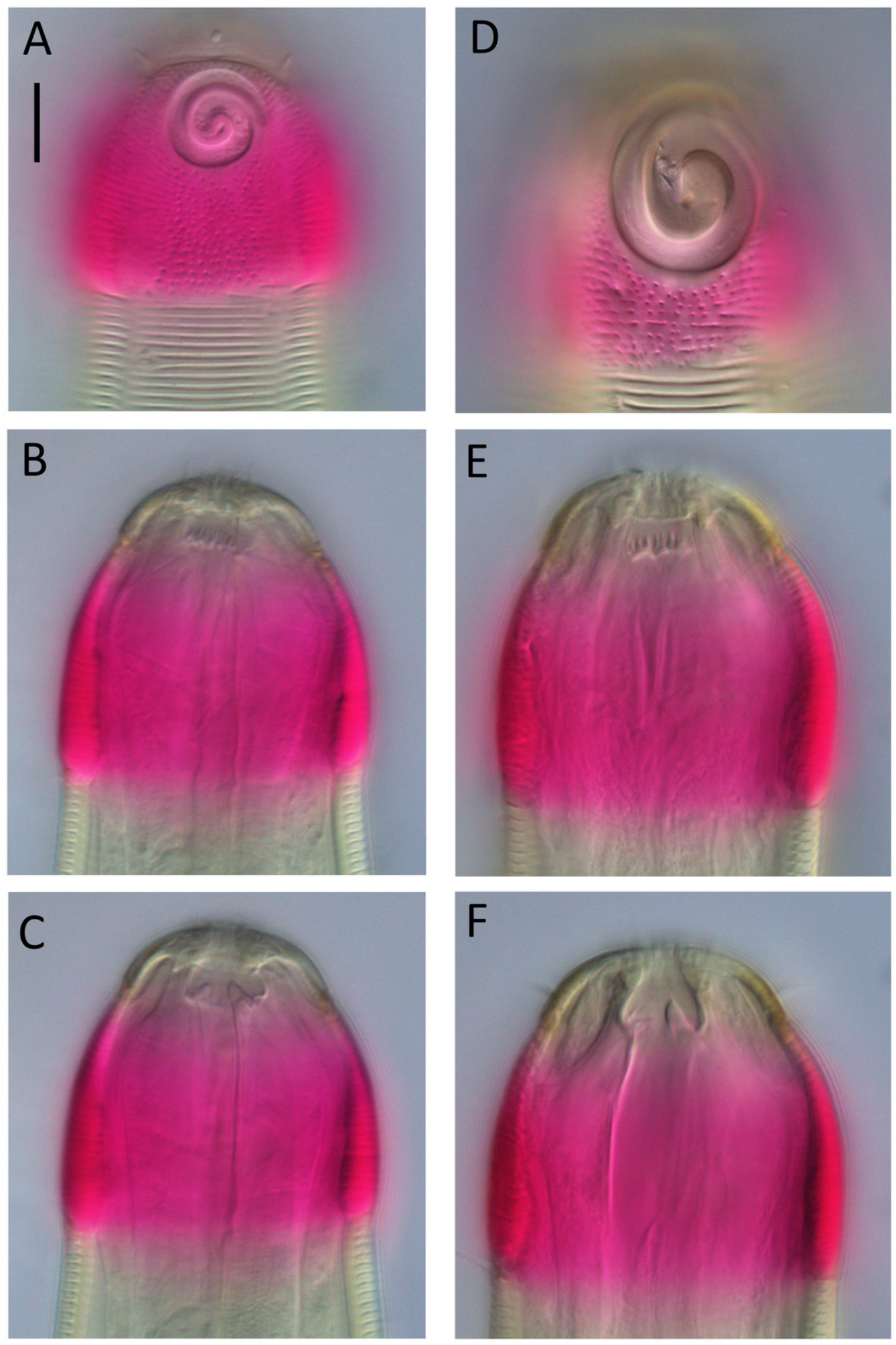